\title{
PSYCHE
}

\begin{tabular}{lll}
\hline VOL. XXVIII FEBRUARY, 1921 No. 1
\end{tabular}

\section{ATHERIX BRAUNSI NOV. SP., A SOUTH AFRICAN LEPTID WITH GREGARIOUS HABITS (DIPTERA).}

By J. BEqUAERT,

American Museum of Natural History, New York City.

The genus Atherix is unique among the Leptidæ on account of the remarkable, gregarious habits exhibited by the adults of certain, if not all, of its meinbers. These have been repeatedly described for the Ibis fly, Atherix ibis (Fabricius), the commonest of the European species. "Ihe female of this fly," says Walker," "is gregarious, and attaches its eggs in large clusters to boughs hanging over streams, and there remains, and shortly dies. The cluster is generally pear-shaped, and sometimes contains many thousands of dead flies, and continually receives accessions by new comers settling upon it. When the larva is hatched it falls into the water, its future residence; it has a forked tail about one-third the length of the body, and has the power of raising itself in the water by an incessant undulating motion in a vertical plane." 2

I am not aware that similar observations have been made on other European species, nor that the metamorphoses of any of these have ever been elucidated. In North America, however, A. variegata Walker, a close ally of $A$. ibis, also oviposits in dense clusters.

1 Walker, F. Insecta Britannica. Diptera. Vol. 1, 1851, p. 70.

2 D. Sharp (The Cambridge Natural History, Insects, Vol. 2, 1909, p. 487. fig. 227) has given a good figure of the egg and fly clusters of A. ibis. Of the many naturalists who have observed the habits of this fly I may mention the following:

Egger, J. Verh. Zool. Bot. Ges. Wien, 4, 1854, p. 7.

Schiner, J. R. Fauna Austriaca, Die Fliegen. Viol. 1, 1862, pp. 177-178.

Chapman A. Masses of Diptera collected on twigs of alder. Ent. Mo. Mag., 3, 1866, pp. 94-95.

Tournier, H. and Preudhomme de Borre, A. Ann. Soc. Ent. Belgique, 17. 1874 , C. R., pp. lxxxix-xci.

Pérez, J.' Actes Soc. Linn. Bordeaux, 32, 1878, C. R., p. xliii.

Billups $T$, Note upon Atherix Ibis, Fabricius. Entomologist, 22, 1889, pp. 193-194, Pl. 7; also mentions and figures parasitic Hymenoptera obtained from the egg cluster; W. H. Ashmead (p. 290) and F. W. Frohawk (pp. 290-291) comment further on these parasites.

Giard, A. Note sur la larve de l'Atherlx Ibis Fabr. Bull. Soc. Ent. France, 1902, pp. $220-222$. 
Ives" describes "a dried-up mass of dead flies, about the size of a man's fist. Throughout it were scattered light-colored fragments, which had somewhat the appearance of empty egg-cases. The whole mass was very brittle, and readily crumbled to pieces. It was obtained (at Pemberton, N. J.) from the under surface of a trunk overhanging a small stream." The flies were recognized by Williston as females of a species belonging to the genus Atherix, probably to Atherix variegata. ${ }^{2}$ In referring to Ives' observations, C. V. Riley and I. O. Howard ${ }^{3}$ add the following remarks: "Some thirteen years ago we collected a large number of these eggs (of Atherix) upon the piling of Lake Minnetonka, near Minneapolis, and they have formed an interesting part of the Dipterological collection of the National Museum, while more recently we received a bit of piling from the shores of Lake Ontario which were covered with these eggs, from which larvæ hatched which we were able to determine as belonging to this genus by comparison with the figures in Dr. Brauer's Monograph of Dipterous Larvæ. Our correspondent stated that wharf piles for hundreds of feet were covered with these eggs."

I am much indebted to Mr. Geo. P. Engelhardt, of the Brooklyn Institute of Arts and Sciences, for the following notes on Atherix variegata, which he observed first at Beaver Creek, Beaver County, I'tah, in July, 1904:4 "The flies were present by thousands in dense clusters attached to the under side of logs and tree trunks a few inches above the water of Beaver Creek, a turbulent mountain stream well stocked with mountain trout. By far the greater part of the flies in the cluster were dead, only a few on the outside being alive. The altitude was about $\%, 000$ feet." Mr. Engelhardt further writes me that "on June 10, 1920, while wading the Carman River, at Yaphank, Long Island, N. Y., a large cluster of leptid flies was observed under about the same conditions as in

1 Ives, J. E. An interesting method of egg deposition. Ent. News, 1, 1890, p. 39.

2 Atherix varlegata Walker occurs in New Jersey. I have seen a number of female specimens of this species in the collections of the American Museum of Natural History, New York; they were taken by Mr. A. J. Weidt, at Singac, N. J., in July. It is not included in J. B. Smith's List of New Jersey Insects (1910).

The eggs of Atherix. Insect Life, 2, Nos. 11-12, 1890, pp. 386-387.

4 Some of the specimens collected on that occasion are preserved in the entomological collections of the Brooklyn Institute, where I have been able to examine them through the kindness of Mr. Chas. S. Schaeffer. 
Beaver Creek, Utah. The time was late afternoon and all the flies were dead." Though, in this last instance, no specimens were collected, this observation most probably also refers to $A$. variegata.

The gregarious habit of the western Atherix has also been observed in Utah and Idaho by Aldrich, who gives an interesting account of the manner in which certain California Indians collect and prepare the masses of these flies for food. ${ }^{1}$ The American Museum of Natural History possesses additional specimens of Atherix variegata obtained by Dr. F. E. Lutz at Pagosa Springs, Colorado ( $\%, 200 \mathrm{ft}$.), June 22 to 24,1919 , and on the Green River, Wyoming (6,100 ft.), July 2, 1920.

It is indeed well worthy of notice that the same gregarious behavior of the adult flies has now been noted in one of the African species, which I have named Atherix braunsi, in honor of its discoverer. There is thus reason to suppose that this curious and thus-far mysterious habit will eventually be observed in many other, if not all, members of the genus. In a recent letter, Dr. H. Brauns, of Willowmore, descrihes the habits of $A$. braunsi as follows: "This fly is of peculiar interest. It is at home along the margin of swiftly running brooks near Cape Town. One finds females and males of it on stones that emerge above the water (the female is smaller and black), bunched together in masses as large as a man's head; every moment pieces the size of a fist break away from the mass and, as soon as they drop in the water, are greedily eaten by the trout with which the streams have been stocked."

\section{Atherix braunsi sp. nov.}

Male. Length $6 \mathrm{~mm}$. Wing, length $7 \mathrm{~mm}$., width $2.4 \mathrm{~mm}$.

Head (Fig 1a) broadly elliptical, as wide as the thorax; one and one-third times as wide as high when seen in front; hemispherical in profile. Inner orbits gradually divergent from the vertex to the side-checks. Front very broad; at its narrowest part, the vertex, about half the width of one eye; at the antennæ nearly half the width of the head. Face short, only half as long as the front, obliquely receding below; the antennæ inserted on the lower third of the head. Epistoma with a deep depression below each of the

1 Aldrich, J. M. Flies of the Leptid genus Atherix used as food by California Indians. Ent. News, 23, 1912, pp. 159-163. 
antennal sockets, slightly raised on the middle line. Posterior orbits moderately broad, gradually narrowed toward the vertex. Ocelli placed in an equilateral triangle, on a slightly raised tubercle which is widely removed from the inner orbits. Proboscis large and thick, slightly shorter than the head; with broad and long labella which are obtusely pointed at the apex. Palpi comparatively short and thick, barely one-third the length of the proboscis. Eyes bare, with all the facets approximately equal in size. Antennæ about as long as the face, of the usual shape in the genus (very much like the drawing of the male antennæ of $A$. ibis in Verrall, British Flies, Vol. 5, 1909, p. 242, fig. 171) ; the two basal joints almost of equal length; the third a little longer, of swollen kidneyshape; arista slender, about one and one-half times the length of the antennæ, bare. Thorax and scutellum of the usual shape.
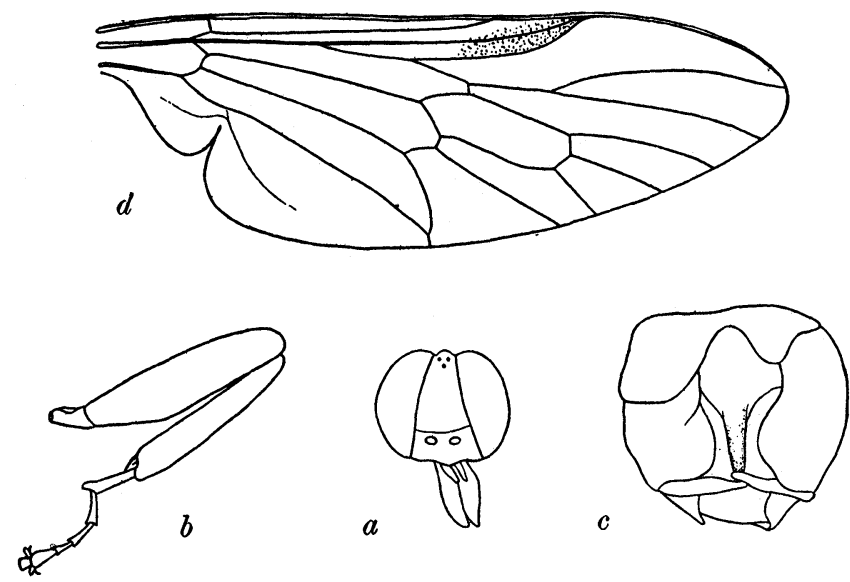

Fig. 1. Atherix braunsl sp. nov. Male: $a$, head seen in front; $b$, hind leg; c, hypopygium from above; d, wing. All $\mathbf{X} 10$.

Legs comparatively long and thick. Femora distinctly swollen and feebly flattened, especially those of the middle and hind legs. Fore and middle tibiæ feebly broadened, much narrower than their femora; the hind tibiæ heavier, but a little narrower than their femora; fore tibiæ without, middle and hind tibiæ with two spurs. Fore tarsi slender, slightly longer than their tibiæ; their basal joint cylindrical, not thickened, about as long as the following four 
joints together. Middle tarsi distinctly shorter than their tibiæ; their basal joint about the length of the following three together and with a feebly projecting, obtuse, apical expansion on the under side. Hind tasi slightly shorter than their tibiæ; their basal joint very short, but a little longer than the following joint; this basal joint is slightly thickened, cylindrical, and ends at the apex in a heavy, broadly obtuse, spur-like expansion which extends on the under side considerably beyond the insertion of the second tarsal joint (Fig. 1b). Pulvilli and claws of the normal shape, even on the fore legs, not distorted as in the male of A. ibis. Abdomen short and broad, but a little longer than the thorax. Hypopygium large, completely exserted; both parts of the forceps elliptical, thick, with a simple, finger-like apical appendage which is folded inward to cover the apex of the penis (Fig. 1c). Wing venation (Fig. $1 d$ ) as in other members of the genus; the third longitudinal vein forked much before the apex of the discal cell, its basal petiole not half the length of the two branches; anal cell closed far from the margin of the wing.

Head and thorax dull dark brown (nearest "mummy brown" of Ridgway's color nomenclature); the antennæ, epistoma and mouth parts pale yellowish; the posterior half of the scutellum dirty ocher yellow. Abdomen, including the hypopygium, uniformly bright ocher yellow. Legs dirty yellow, the coxæ and tips of tarsal joints slightly infuscate; the spur-like processes of basal joints of hind tarsi blackish. Halteres white, with a faint yellowish tinge. Wings hyaline, somewhat milky white, with a feebly marked, pale brown stigma which extends between the first and second longitudinal veins, from slightly before the anterior cross-vein to the apex of the first vein; wings otherwise entirely without spots or bands.

Pubescence concolorous, short but rather abundant on head and thorax; covering the entire vertex, front and side cheeks; face around the antennal sockets and epistoma bare. Hairs much longer and denser on the abdomen, bright yellow with a slight golden suffusion. Upper side of the femora with long, pale pubescence; the hairs of the legs otherwise short and black. No tactile hairs on the fore tarsi; but on the fore femora an irregular, transverse row of five long, pale colored bristles, which are placed before the 
middle at the lower edge and are directed obliquely towards the apex of the femur; these bristles are in all probability tactile hairs.

Described from two males taken by Dr. H. Brauns at Stellenbosch, Cape Province, South Africa, November, 1915.

According to Dr. H. Brauns, females, seen at the same place and under the same conditions, therefore evidently of the same species, were smaller and black. I have not seen examples of that sex.

The salient characters of $A$. braunsi are found in the broad front of the male, the spur-like apex of the hind metatarsus, the unicolorous ocher yellow abdomen, and the milky white, unspotted wings. By these characters it differs conspicuously from all other described species and can easily be distinguished from the two previously known in the Ethopian Region: Atherix binominata J. Bequaert (= Atherix longipes Lœw, neo Bellardi) ${ }^{1}$ from Bloemfontein, Orange River Colony; and A. disciclara Speiser, ${ }^{2}$ from Tiko, near Victoria, Kamerun. Lœw campares $A$. binominata with $A$. crassipes Meigen, but that species has been made the type of Atrichops Verrall ${ }^{3}$ on account of the front in the male and the side-cheeks in both sexes being practically bare. Whether $A$. binominata agrees in this respect with $A$. crassipes seems extremely doubtful; but $A$. braunsi has the front densely hairy from the ocelli to a short distance above the antennæ and the side-cheeks also are pubescent.

The genus Atherix Meigen (including Atrichops Verrall) is known from all over the world with the exception of South America. Of the thirty-one described species two are doubtful, seven occur in the Palearctic Region, three in the Ethiopian, eleven

1 Atherix longlpes H. Loew, Wiener Ent. Monatschr., 7, 1863, p. .12. This specific name being preoccupied in the genus by Atherix longlpes Bellardi (1861) of Mexico, I propose that Loew's South African species be called Atherix blnominata.

For the convenience of South African entomologists Loew's brief description of A. binominata is reproduced here: "- Ex Ather. crassipedis affinibus Fusco-nigra, tertio antennarum articulo, scutelli margine abdomineque subfulvis, primo hujus segmento praeter marginem apicalem atro, segmento secundo maculis tribus atris ornato, segmentis tribus sequentibus atro-fasciatis, segmento sexto subtiliter atro-marginato; pedes longi, cum coxis fulvotestacei, tibiis tarsisque anterioribus tarsisque posticas praeter basim nigris, tibils posticis tarsorumque posticorum basi fuscis; alae infuscatae, in disco subnebulosae, stigmate fusco, furca .venae longitudinalis tertiae perlonga. Long. corp. $3 \frac{1}{4}$ lin.-Long. al. $31 / 4$ lin."

2 Deutsch. Ent. Zeitschr., 1914, p. 3 ( ).

${ }^{8}$ British Flies. Vol. 5. Stratiomyidæ. 1909. p. 291. 
in the Oriental, one in Australia, and seven in North and Central America. To these should be added three Oriental species of Suragina Walker, which, according to Bezzi, ${ }^{1}$ is not generically distinct from Atherix. In addition, a number of fossil species have been described from Baltic amber (Lower Oligocene) and from the Miocene shales of Florissant, Colorado. ${ }^{2}$

As suggested by Knab, ${ }^{3}$ it is by no means certain that all the species included at present in Atherix are congeneric. In this connection it is of considerable interest that the female of the Mexican Atherix longipes Bellardi has been reported as a fierce biter and blood-sucker, a habit unknown in the common European A. ibis and in the North American A. variegata. ${ }^{4}$

1 Ann. Mus. Nat. Hungarici, 10, 1912, p. 445.

2 Atrichops hesperius Cockerell, Canadian Entomologist, 46, 1914, p. 101.

3 Proc. Ent. Soc. Washington, 14, 1912, pp. 186-187.

4 Knab, F. Blood-sucking and supposediy blood-sucking Leptidæ. Proc. Ent. Soc. Washington, 14, 1912, pp. 108-110.

\section{A NEW PTINID FOR NEW ENGLAND.}

On November 3rd, Dr. J. Payson Clark of Boston brought to the Boston Society of Natural History a small beetle that he was frequently finding in his house. I could not name it at the time, but a few days later, Mr. H. C. Fall determined it as Niptus hololeucus Hald., a European species, the only previous record for North America being Montreal, Canada. Dr. Clark continued finding a few each week, and as late as December $2 \%$. In all, some thirty-five specimens were obtained.

C. W. JoHnson.

\section{SYMPETRUM CORRUPTUM IN MASSACHUSETTS.}

On September 10, 1911, I took two males and one female of this dragonfly at the south end of Plum Island, Ipswich, Mass. This is, I believe, the first record of this species in Massachusetts. At the same time and place I also secured a female of Tramea lacerata, making the second record of that species for New England, the first having been taken at Chelsea Beach about fifty years ago, and the specimen being now in the collection of the Boston Society of Natural History. The first specimens referred to are in the Essex County collection of the Peabody Museum of Salem, Mass.

A. P. Morse. 

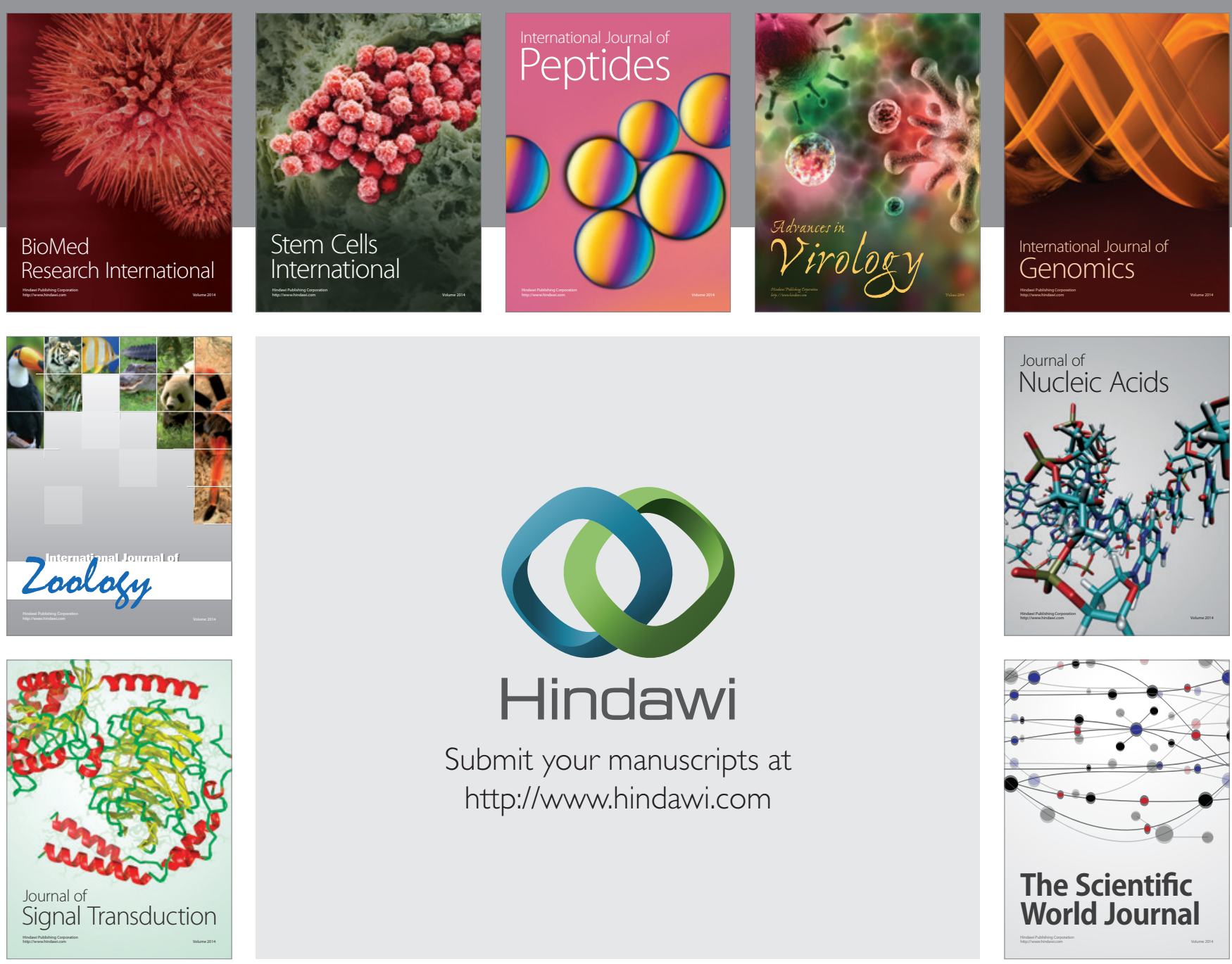

Submit your manuscripts at

http://www.hindawi.com
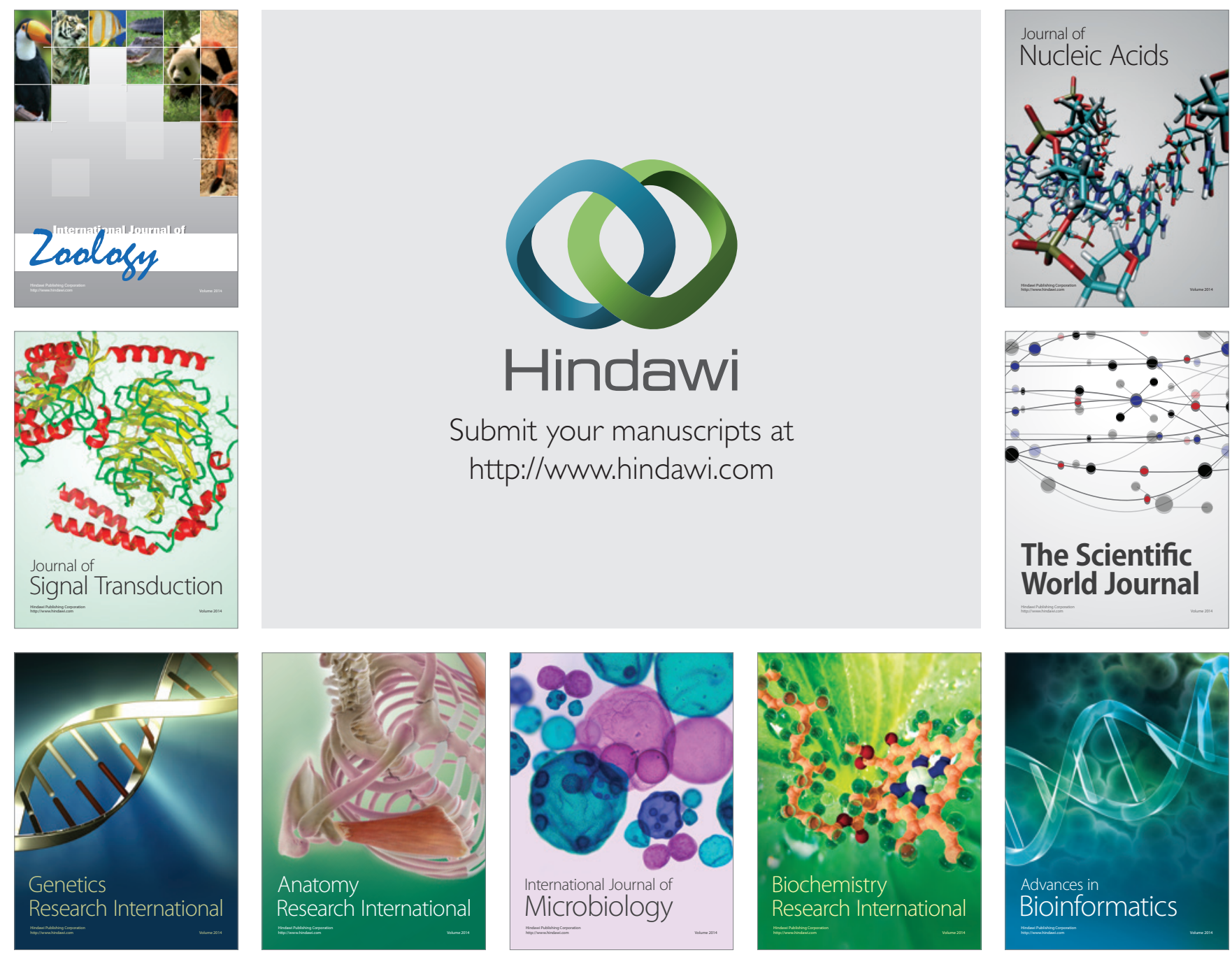

The Scientific World Journal
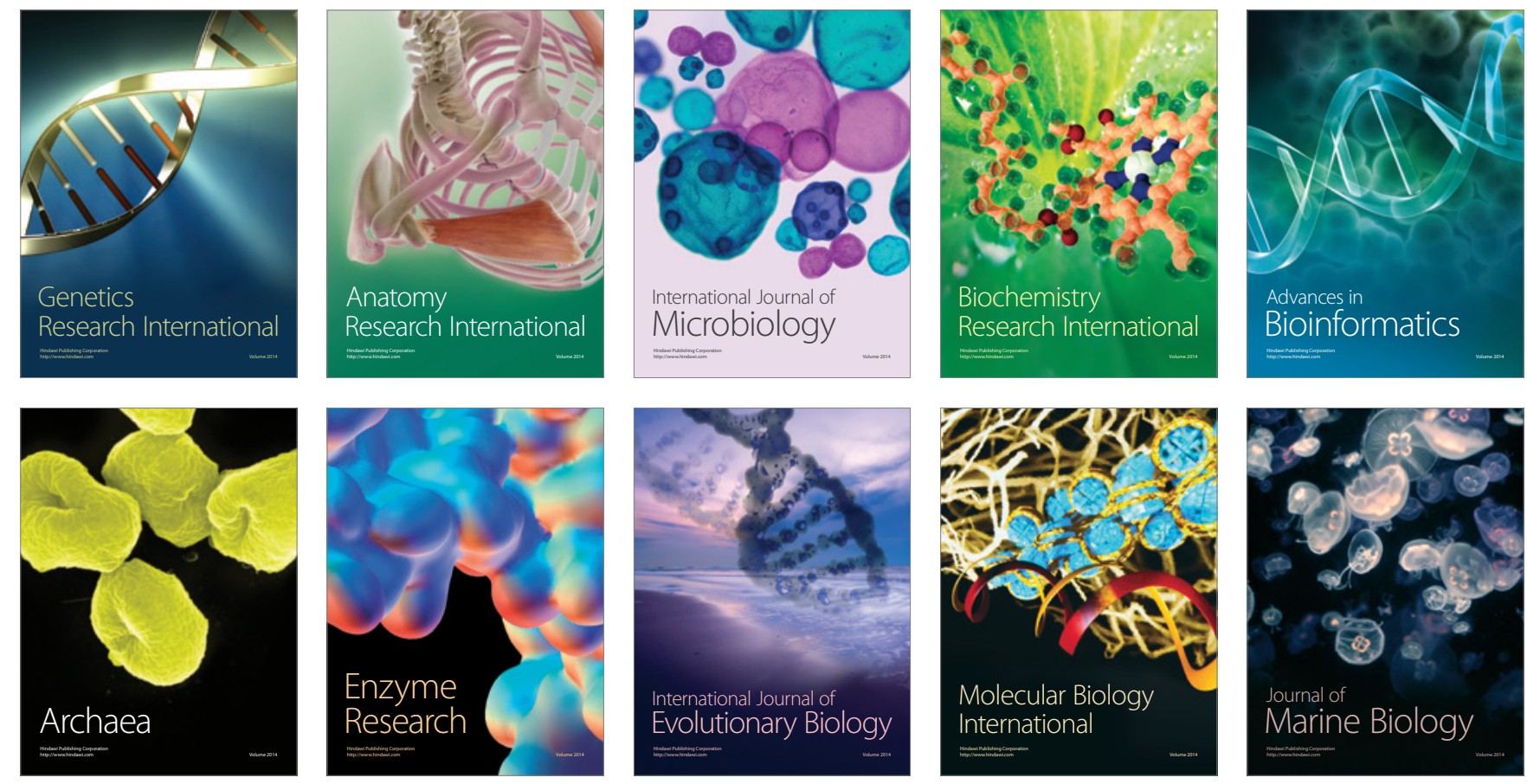